\title{
THE PEA GRIT OF CLEEVE HILL.
}

Sir,-I thank Mr. Witchell for his courteous correction of my figures in the thickness of the Pea-grit, and underlying Ferruginous Oolite in the Cleeve Hill Section, which I quoted in my letter in the Geological Magazine for November last. The error occurred in the numbers of the beds being inserted as feet, and the three figures were transferred to the inch column. Mr. Witchell remarks that "the correct, reading confirms my statement, except as regards the lowest 5 feet." Exactly, but the exception makes all the difference; if there are only 5 feet of Oolite under the Pea-grit beds at Cleeve Hill, then Dr. Wright could not make the thickness more, and as I understand Mr. Witchell, in his paper in the Quarterly Journal of the Geological Society, he maintains that the basement beds were overlooked by Dr. Wright. Mr. Witchell in his paper says, "The beds next above the Cephalopoda-bed are usually brown sandy limestones in two or three beds, varying in thickness from 5 feet at Cleeve Hill." 1

Now I think it would have been fairer to Dr. Wright if $\mathrm{Mr}$. Witchell had given a reference to Dr. Wright's Cleeve Hill section where that fact was first mentioned. Doubtless in the Stroud area the basement beds assume a greater importance than Dr. Wright recognized, but of course he had to be guided by the available exposures of the strata in bis day.

I do not think I need argue the matter further, as Mr. Witchell seems to me to admit my contention, viz. that the late Dr. Wright in his sections of Cleeve Hill and Leckhampton showed that there were Oolitic beds below the Pea-grit proper. Edward Wethered.

\section{THE COLLINGHAM OR SCARLE BORING.}

SrR,-The alternative figures, given by me, as Reporter to the British Association Underground Water Committee, on the anthority of Mr. W. H. Dalton, are correctly copied from a lithographed copy of a report by him to the Gainsborough Board of Health, "On the Water Supply obtained from Underground Sources at Gainsborough," handed to me by the Board on the 24th of October, 1884, and now before me.

On the 1st of November, of that year, I recommended the Board to sink an artesian boring at Gainsborough to a depth of 750 feet: this proposal was adopted, and I have to-day learnt by telegraph that the contractors, Messrs. Timmins, of Runcorn, have penetrated the Keuper Marls, and reached the Sandstone at a depth of 725 feet from the surface.

C. E. De Ranck.

54, West Paraue, Rhyt.

\section{FOLKESTONE GAULT.}

Sir,-Mr. John Griffiths, of Folkestone, the well-known collector of Gault fossils, is without resources and is permanently disabled by rheumatism brought on by exposure in his daily labours, which have

1 Q. J. G. S. vol. xlii. p. 267. 
not only enriched the Museums of Europe and the United States, but have formed the groundwork of the investigations into the zones and fossils of the Gault made by myself, and fellow-workers-the Rev. Professor Wiltshire before my own endeavours, and those of Mr. F. G. H. Price, F.G.S., and Mr. Starkie Gardner, F.G.S., since. Mr. F. G. H. Price, of Messrs. Child's Bank, Temple Bar, W.C., has kindly undertaken to receive subscriptions for the "Griffiths Fund."

H.M. Geological Survey. $\quad$ C. E. De Rance, F.G.S.

\section{OBITUARY. \\ CALEB EVANS, F.G.S., MEMB. GEOL. ASSOC. \\ Bonn July, 1831 ; Died Sept. 16, 1886.}

THE subject of our present Memoir was a resident of Hampstead. He was educated at University College School, and so early as in 1846 he entered a solicitor's office, and was appointed Clerk in the Chancery Pay-Office in 1852 , where he served for 30 years, but retired on account of ill-health in $\mathbf{1 8 8 2}$.

He commenced to study geology about the year 1855, and attended lectures by Prof. Owen and Dr. Melville. He made no actual collection of specimens until 1858 , but from that time until his health gave way, he took advantage of his annual official vacations to visit the various localities of geological interest, especially those of the South-East of England. In 1859 he became a member of the Geologists' Association, and in 1867 he was elected a Fellow of the Geological Society of London. The beds to which he chiefly directed his attention were those of the English Tertiaries and the Chalk, and in addition to a large collection from the Isle of Wight and Hampshire beds, he obtained numerous London Clay fossils by watching the excavations in various parts of the Metropolis, and more especially from the main-drainage works in the South of London, which yielded numerous fossils of the Woolwich and Reading Series, from strata then exposed for the first time, and which have never been accessible since in this particular area.

Mr. Evans was author of eleven papers, eight of which appeared in the Proceedings of the Geologists' Association, the most important being that "On the Geology of the Neighbourhood of Portsmouth and Ryde." But the paper by which he will be best known was that read before the Geologists' Association in January, 1870, entitled, "On some Sections of Chalk between Croydon and Oxtead," which was separately published. It was the first attempt made in this country to subdivide the Chalk into zones according to their fossil contents, and to correlate these zones with those in other parts of England and on the Continent.

Mr. Evans constructed several geological relief-maps or models, based on his own observations; one of the neighbourhood of Hampstead and Highgate; one of the Thames Valley in the neighbourhood of London; one of Hastings, one of Sidmouth, and one of England 